\title{
Multivariate Statistical Analysis of Multiple- Elements in Anisodus Tanguticus (Maxim.) Pascher from Different Regions to Determine Geographical Origins
}

\section{Chen Chen}

Northwest Institute of Plateau Biology Chinese Academy of Sciences https://orcid.org/0000-00017696-2474

Jingjing Li

Qinghai Normal University

\section{Bo Wang}

Northwest Institute of Plateau Biology Chinese Academy of Sciences

\section{Feng Xiong}

Northwest Institute of Plateau Biology Chinese Academy of Sciences

\section{Yuanming Xiao}

Northwest Institute of Plateau Biology Chinese Academy of Sciences

GuoYing Zhou ( $\square$ zhougy@nwipb.cas.cn )

Northwest Institute of Plateau Biology Chinese Academy of Sciences https://orcid.org/0000-00032485-6172

\section{Research}

Keywords: multi-element, principal component analysis, orthogonal partial least-squares discriminant analysis, element accumulation, element transfer

Posted Date: December 20th, 2021

DOI: https://doi.org/10.21203/rs.3.rs-1154239/v1

License: (c) (1) This work is licensed under a Creative Commons Attribution 4.0 International License. Read Full License 


\section{Abstract}

Background: Anisodus tanguticus (Maxim.) Pascher, which is an important species used in traditional Tibetan medicine, is grown in the Qinghai -Tibet Plateau. Because the quality of $A$. tanguticus varies depending on where it is grown, a method for determining the geographical origin of this species is needed.

Methods: A quantitative analysis of 18 elements (Al, Ba, Be, $\mathrm{Ca}, \mathrm{Co}, \mathrm{Cu}, \mathrm{Fe}, \mathrm{K}, \mathrm{Li}, \mathrm{Mg}, \mathrm{Mn}, \mathrm{Mo}, \mathrm{Na}, \mathrm{Ni}, \mathrm{P}, \mathrm{Sr}$, $\mathrm{V}$, and $\mathrm{Zn}$ ) in A. tanguticus and the soil collected from different locations was conducted using an inductively coupled plasma optical emission spectrometer. The elemental contents underwent a principal component analysis (PCA), and an orthogonal partial least-squares discriminant analysis (OPLS-DA). Furthermore, elemental accumulation and elemental transfer coefficients were calculated according to the element concentration gradients.

Results: Distinct element fingerprints were detected for the $A$. tanguticus collected from different regions. Additionally, the PCA and OPLS-DA results indicated A. tanguticus plants can be distinguished on the basis of their geographical origin. The Tibet samples were easily separated from the other samples. Elemental accumulation and transfer patterns differed significantly among the analyzed elements and plant parts. $\mathrm{Ca}$ and $\mathrm{P}$ were identified as the elements with the highest in elemental accumulation and elemental transfer patterns of $A$. tanguticus.

Conclusions: Our approach can be used to efficiently and accurately distinguish herbs according to their varietal characteristics and geographical origins.

\section{Introduction}

Anisodus tanguticus (Maxim.) Pascher, which belongs to the family Solanaceae, is an herb that is mainly grown in the Qinghai -Tibet Plateau, China [1]. The name for this species when used in traditional Tibetan medicine is "Tang Chun $\mathrm{Na} \mathrm{Bao".} \mathrm{It} \mathrm{has} \mathrm{been} \mathrm{used} \mathrm{to} \mathrm{treat} \mathrm{septic} \mathrm{shock,} \mathrm{analgesia,} \mathrm{and} \mathrm{motion} \mathrm{sickness,}$ as well as an anesthesia [2]. A. tanguticus is a natural source of tropane alkaloids with pharmacological effects, including atropine, anisodamine, anisodine, and scopolamine. These compounds are used as narcotics, sedatives, analgesics, and antispasmodics as well as for treating Parkinson's disease, motion sickness and asthma [3-5]. Sales of tropane alkaloid-based drugs, which are mostly derived from $A$. tanguticus in China, can be as high as about 200 million. However, the quality and efficacy of $A$. tanguticus vary among samples. Thus, determining the geographical origin of plants is important for maintaining the high quality of commercially produced herbs.

Geographical origin is one of the most important parameters for many herbs, because the diversity in climate and soil conditions can influence the quality of herbs. Various techniques, including highperformance liquid chromatography (HPLC), gas chromatography (GC), HPLC coupled with mass spectrometry (HPLC-MS), near infrared reflectance (NIR) spectroscopy, inductively coupled plasma optical emission spectrometer (ICP-OES), and inductively coupled plasma mass spectrometry (ICP-MS), 
combined with chemometric methods have recently been used to discriminate the geographical origin of herbs and other food and agricultural products [6-10].

Elemental compositions in plants can reflect the environmental elemental compositions in different geographical locations. Thus, ICP-MS/OES may be appropriate for determining the geographical origin of foods and herbs. Unlike the chemical composition, the elemental composition of plants is an inherent property that is relatively stable. Elemental contents in plants are influenced by plant characteristics as well as environmental factors, including soil and climate conditions. For example, the geographical origins of three Ephedra species were revealed by ICP-MS. Similar strategies have been used to discriminate various regions in which herbs and food crops originated as well as to identify the variables important for authentication [11-13]. To date, there have been no studies that systematically distinguished geographical origins of $A$. tanguticus samples on the basis of multiple-elements. In this study, we combined multi-element fingerprinting and a multivariate statistical analysis to elucidate the geographical origins of $A$. tanguticus.

Soil is one of the main factors influencing the element fingerprints of plants. Regarding the dynamics of the soil -plant element system, plants absorb elements from the soil through their roots, after which the elements are transported to different tissues. This absorption and transport can vary depending on the plant species and the type of element [14-16]. Therefore, it is necessary to study the relationships between different plant tissues and the soil.

The objectives of this study were as follows: (1) establish the element fingerprints of different parts of $A$. tanguticus collected from the Qinghai -Tibet Plateau by ICP-OES; (2) develop a method for a multivariate statistical analysis that classifies $A$. tanguticus according to its geographic origin. (3) clarify the relationship between the elements in $A$. tanguticus and soil.

\section{Results}

\section{General features of the analyzed elements}

The contents of the 18 analyzed elements (Al, Ba, Be, Ca, Co, Cu, Fe, Li, K, Mg, Mn, Mo, Na, Ni, P, Sr, V, and $\mathrm{Zn}$ ) in the AAT, RAT and soil samples are listed in supplementary material, and the data are presented as mean \pm standard deviation. The elemental contents in different parts of $A$. tanguticus plants and in the soil differed significantly among the sampling locations.

Several of the examined elements ( $\mathrm{Ca}, \mathrm{Na}, \mathrm{K}, \mathrm{P}, \mathrm{Mg}$, and $\mathrm{Fe}$ ) are important for multiple physiological processes. The mean $\mathrm{Ca}, \mathrm{Na}, \mathrm{K}, \mathrm{P}, \mathrm{Mg}$ and Fe contents at the different locations were respectively 13085.2 $\mathrm{mg} / \mathrm{kg}, 360.2 \mathrm{mg} / \mathrm{kg}, 14005.0 \mathrm{mg} / \mathrm{kg}, 1915.6 \mathrm{mg} / \mathrm{kg}, 5491.2 \mathrm{mg} / \mathrm{kg}$, and $936.2 \mathrm{mg} / \mathrm{kg}$ in AAT, and $10744.8 \mathrm{mg} / \mathrm{kg}, 327.2 \mathrm{mg} / \mathrm{kg}, 4016.1 \mathrm{mg} / \mathrm{kg}, 2019.3 \mathrm{mg} / \mathrm{kg}, 2775.1 \mathrm{mg} / \mathrm{kg}$, and $747.1 \mathrm{mg} / \mathrm{kg}$ in RAT. Calcium is important for preventing of dyslipidemia, arterial hypertension, and osteoporosis [17]. Potassium has important cellular functions, especially in the nervous system [18]. Both $\mathrm{Mg}$ and $\mathrm{Fe}$ are essential micronutrients, with $\mathrm{Mg}$ is required for nucleic acid in protein synthesis and Fe mainly 
contributing to the synthesis of hemoglobin $[19,20]$. Some studies have indicated that people exposed to high levels of aluminum may develop Alzheimer's disease, but other studies were unable to verify this relationship. The $\mathrm{Ca}, \mathrm{Na}, \mathrm{K}, \mathrm{P}, \mathrm{Mg}$, and Fe contents in the AAT and RAT samples determined in this study suggest $A$. tanguticus is an important herb for mineral supplementation, especially for people with deficiencies in these minerals.

The mean value of $\mathrm{Ba}, \mathrm{Be}, \mathrm{Cu}, \mathrm{Li}, \mathrm{Mn}, \mathrm{Sr}, \mathrm{V}$, and $\mathrm{Zn}$ elements at different locations were respectively 27.7 $\mathrm{mg} / \mathrm{kg}, 11.3 \mathrm{mg} / \mathrm{kg}, 12.2 \mathrm{mg} / \mathrm{kg}, 35.4 \mathrm{mg} / \mathrm{kg}, 68.8 \mathrm{mg} / \mathrm{kg}, 44.7 \mathrm{mg} / \mathrm{kg}, 29.2 \mathrm{mg} / \mathrm{kg}, 23.9 \mathrm{mg} / \mathrm{kg}$ in AAT, and $35.8 \mathrm{mg} / \mathrm{kg}, 16.4 \mathrm{mg} / \mathrm{kg}, 19.2 \mathrm{mg} / \mathrm{kg}, 75.8 \mathrm{mg} / \mathrm{kg}, 36.2 \mathrm{mg} / \mathrm{kg}, 60.1 \mathrm{mg} / \mathrm{kg}, 19.1 \mathrm{mg} / \mathrm{kg}$, and 36.1 $\mathrm{mg} / \mathrm{kg}$ in RAT. The essential metals Cu and Zn serve as enzymatic cofactors that are crucial for the immune, central nervous, and reproductive systems [21]. There are several adverse effects associated with a lack of $\mathrm{V}$, including anemia and abnormal iron metabolism [22].

The mean value of Co, Mo, and $\mathrm{Ni}$ at the different locations were respectively $2.2 \mathrm{mg} / \mathrm{kg}, 4.8 \mathrm{mg} / \mathrm{kg}, 16.3$ $\mathrm{mg} / \mathrm{kg}$ in AAT, and $7.9 \mathrm{mg} / \mathrm{kg}, 0.8 \mathrm{mg} / \mathrm{kg}$, and $11.2 \mathrm{mg} / \mathrm{kg}$ in RAT. An analysis of the mean contents in the ATT and RAT samples revealed that the most abundant element was $\mathrm{Ca}$, with concentrations exceeding $10000 \mathrm{mg} / \mathrm{kg}$. The $\mathrm{K}$ content in AAT was also greater than $10000 \mathrm{mg} / \mathrm{kg}$. The P, Mg Al, Fe, and $\mathrm{Na}$ contents in the ATT and RAT samples were greater than $1000 \mathrm{mg} / \mathrm{kg}$. The concentrations of the remaining elements exceeded $10 \mathrm{mg} / \mathrm{kg}$.

Regarding the soil elemental abundance, the mean value of 18 elements in soil were $59657.9 \mathrm{mg} / \mathrm{kg}$, $370.7 \mathrm{mg} / \mathrm{kg}, 7.8 \mathrm{mg} / \mathrm{kg}, 13099.7 \mathrm{mg} / \mathrm{kg}, 32.7 \mathrm{mg} / \mathrm{kg}, 73.9 \mathrm{mg} / \mathrm{kg}, 32549.4 \mathrm{mg} / \mathrm{kg}, 66.7 \mathrm{mg} / \mathrm{kg}, 10124.9$ $\mathrm{mg} / \mathrm{kg}, 8747.6 \mathrm{mg} / \mathrm{kg}, 1268.8 \mathrm{mg} / \mathrm{kg}, 92.7 \mathrm{mg} / \mathrm{kg}, 11747.3 \mathrm{mg} / \mathrm{kg}, 107.5 \mathrm{mg} / \mathrm{kg}, 948.4 \mathrm{mg} / \mathrm{kg}, 155.5$ $\mathrm{mg} / \mathrm{kg}, 110.3 \mathrm{mg} / \mathrm{kg}$, and $121.1 \mathrm{mg} / \mathrm{kg}$, respectively.

The multi-element fingerprint map of $A$. tanguticus at different locations was established and is presented in Fig. 1. The lowest and highest elemental contents varied among the locations. For example, $\mathrm{QH} 22$ had the highest $\mathrm{Ca}, \mathrm{Mn}$, and Ni contents in the AAT samples and QH2 had the lowest $\mathrm{Ba}$ and $\mathrm{Mg}$ contents in the AAT samples. Additionally, XZ22 had the highest $\mathrm{Mg}$ and $\mathrm{V}$ contents in the RAT samples and GS3 had the lowest $\mathrm{Cu}, \mathrm{K}, \mathrm{Mn}$, and $\mathrm{Zn}$ contents in the RAT samples. Thus, the multi-element fingerprint of $A$. tanguticus at different locations revealed elemental variations. The general features of the elements in $A$. tanguticus indicated that plants originating from specific regions have characteristic elemental contents. Furthermore, the element fingerprints varied substantially, reflecting the considerable diversity among the examined regions.

\section{Principal component analysis}

A PCA of the elemental contents of the AAT, RAT, and soil samples was conducted as an exploratory data analysis before the classification modeling. The auto-scaled data matrix was applied for the PCA, to facilitate a data structure study in a reduced dimension. Four extracted principal components (PCs) with eigenvalues explained $53 \%$ of the total variance. More specifically, PC1, PC2 and PC3 explained $28 \%, 11 \%$ and $8 \%$ of the total variance, respectively. Additionally, PC1 was associated with the most variables (K, 
$\mathrm{Mg}, \mathrm{Mo}, \mathrm{Fe}$, and $\mathrm{Al}$ ) among the soil samples, whereas PC2 was associated with the most variables (Cu Ni, $\mathrm{Zn}$, and $\mathrm{K}$ ) among the RAT samples.

The PCA score plot generated for 67 samples (Fig. 2a) clearly divided the samples from the various locations into three groups. The XZ samples could be distinguished from the GS, SC, and QH samples along the PC2 axis. Most of the GS samples could be distinguished from the SC samples along the PC1 axis. However, the QH samples could not be distinguished from the other samples along the PC1 axis. There was a considerable overlap between the $\mathrm{QH}$ samples and SC samples as well as between the QH samples and the GS samples. According to Fig. 2b, the XZ samples were positively correlated with PC1; thus, they were characterized on the basis of five elements ( $\mathrm{K}, \mathrm{Mg}, \mathrm{Mo}, \mathrm{Fe}$, and $\mathrm{Al}$ in soil). The Be, Co, $\mathrm{Ni}$, and Mo contents in the RAT samples and the Be and Cu contents in the AAT samples were negatively associated with PC1. The $\mathrm{Cu}, \mathrm{Mn}$, and Zn contents in the RAT samples were highly positively correlated with $\mathrm{PC} 2$, which was in contrast to the highly negative correlations between the $\mathrm{Ca}, \mathrm{Fe}$, and $\mathrm{Sr}$ contents in AAT samples and PC2. Hence, the XZ samples most affected by the soil K, Mg, Mo, Fe, and Al contents whereas the GS, SC, and QH samples were most affected by the RAT $\mathrm{Be}, \mathrm{Co}, \mathrm{Ni}$, and Mo contents and the AAT Be and Cu contents.

Clearly, the results reflected the utility of the PCA for distinguishing $A$. tanguticus samples from different locations. Next, an OPLS-DA was performed to assess sample authenticity.Orthogonal partial least squares discriminant analysis

The OPLS-DA of the AAT, RAT, and soils elemental contents was conducted to further separate the $A$. tanguticus samples according to their geographical origins. The OPLS-DA model presented the sample classification results in a scores chart (Fig. 3a). An R2Y of 0.903 , and a Q2 of 0.794 , suggested the model appropriate for generating accurate predictions [23].

The samples from the different regions were classified into three groups. The XZ samples were clearly separated from the GS, SC, and QH samples. There was some overlap between the GS and SC samples. The loading distribution of the variables indicated that the $\mathrm{XZ}$ samples could be identified on the basis of $\mathrm{Be}, \mathrm{K}$ Mo Fe, and Al in soil (Fig. 3b). In contrast, the Be contents in the AAT and RAT as well as the Ni, Co, Mo contents in RAT samples were more useful for identifying the samples from the other locations. The variable importance of projection plot (Fig. 3c) identified the following as the most important discriminant variables: $\mathrm{Ni}, \mathrm{Cu}, \mathrm{Mo}, \mathrm{Mn}, \mathrm{Be}, \mathrm{Co}, \mathrm{V}, \mathrm{Zn}, \mathrm{Al}$, and $\mathrm{Fe}$ in the RAT samples; $\mathrm{K}, \mathrm{Mo}, \mathrm{Be}, \mathrm{Al}, \mathrm{Fe}, \mathrm{Mg}$, $\mathrm{Na}, \mathrm{Ba}, \mathrm{Li}$, and $\mathrm{Sr}$ in the soil samples, and $\mathrm{Li}, \mathrm{Be}$ and $\mathrm{Cu}$ in the AAT samples.

\section{Elemental relationship}

All elements were analyzed by plotting the correlation matrix using Pearson's associations (Fig. 4).

Significant correlations were detected between the elemental contents. For example, there were significant correlations between Al in AAT and Fe in RAT ( $r>0.85)$, as well as between the Mg in AAT and $V$ in RAT $(r>0.85)$. The Be content in RAT was significantly correlated with the Mo content in RAT ( $r$ 
0.90). Similarly, Be content in RAT and Ni content in RAT have a significant correlation $(r>0.90)$. The soil Al content was significantly correlated with the RAT Ba, Be Fe, K, and Mo contents $(r>0.70)$.

The AF represents the capacity of plants to accumulate elements from the soil, whereas TF reflects the transport of elements from the roots to aerial parts, which is important for the growth and development. The mean AF and TF value at the different sampling locations are listed in Table 1. The AF values indicated the plants were better able to take up Al, $\mathrm{Ca}, \mathrm{Fe}, \mathrm{K}, \mathrm{Mg}, \mathrm{Mn}, \mathrm{Na}, \mathrm{P}$ and $\mathrm{V}$ from the soil than the other elements. In terms of plant growth and development, $\mathrm{Ca}, \mathrm{Fe}, \mathrm{K}, \mathrm{Mg}, \mathrm{Mn}, \mathrm{Na}$, and $\mathrm{P}$ are the major required element. Calcium binds to pectin, which strengthens growing plants. Potassium contributes to the maintenance of vigor which also affecting storability. Notably, although $\mathrm{Mg}$ is a central atom of the light-absorbing complex in chloroplasts, the TF value of $\mathrm{Mg}$ was relatively low [24].

Table 1

The mean AF and TF value of sampling locations

\begin{tabular}{|lll|}
\hline Element & $\mathrm{AF}$ & $\mathrm{TF}$ \\
\hline $\mathrm{Al}$ & $1.88 \pm 1.82$ & $0.01 \pm 0.01$ \\
\hline $\mathrm{Ba}$ & $0.94 \pm 0.59$ & $0.21 \pm 0.76$ \\
\hline $\mathrm{Be}$ & $0.8 \pm 0.24$ & $3.55 \pm 3.98$ \\
\hline $\mathrm{Ca}$ & $1.52 \pm 1.2$ & $1.43 \pm 4.05$ \\
\hline $\mathrm{Co}$ & $0.66 \pm 0.7$ & $0.36 \pm 0.48$ \\
\hline $\mathrm{Cu}$ & $1.10 \pm 1.94$ & $0.38 \pm 0.37$ \\
\hline $\mathrm{Fe}$ & $2.18 \pm 2.72$ & $0.02 \pm 0.02$ \\
\hline $\mathrm{Li}$ & $0.59 \pm 0.59$ & $1.60 \pm 1.60$ \\
\hline $\mathrm{K}$ & $4.01 \pm 3.26$ & $0.46 \pm 0.22$ \\
\hline $\mathrm{Mg}$ & $2.31 \pm 1.37$ & $0.45 \pm 0.59$ \\
\hline $\mathrm{Mn}$ & $2.64 \pm 2.72$ & $0.04 \pm 0.03$ \\
\hline $\mathrm{Mo}$ & $0.80 \pm 0.82$ & $0.18 \pm 0.21$ \\
\hline $\mathrm{Na}$ & $2.01 \pm 2.12$ & $0.03 \pm 0.03$ \\
\hline $\mathrm{Ni}$ & $1.00 \pm 0.87$ & $0.13 \pm 0.13$ \\
\hline $\mathrm{P}$ & $1.06 \pm 0.53$ & $2.48 \pm 1.27$ \\
\hline $\mathrm{Sr}$ & $0.85 \pm 0.47$ & $0.55 \pm 0.48$ \\
\hline $\mathrm{V}$ & $2.78 \pm 5.11$ & $0.20 \pm 0.13$ \\
\hline $\mathrm{Zn}$ & $0.73 \pm 0.38$ & $0.36 \pm 0.29$ \\
\hline
\end{tabular}




\section{Discussion}

The elemental contents in A. tanguticus were in accordance with the relevant data produced in earlier studies on traditional Tibetan medicine. For example, in previous investigations of $A$. tanguticus cultivated in Qinghai, the $\mathrm{Co}, \mathrm{Cu}, \mathrm{Fe}, \mathrm{Mg}, \mathrm{Mn}$, and $\mathrm{Zn}$ contents determined by $\mathrm{Xu}$ et al., and Li et al. [2527], were similar to the corresponding concentrations in the current study; however, the $\mathrm{Ca}, \mathrm{K}$, and $\mathrm{P}$ contents are apparently lower in cultivated $A$. tanguticus than in wild $A$. tanguticus. The contents of 10 elements in Tibetan medicine Hypecoum leptocarpum Hook. f. et Thoms. collected from different locations in a previous study were similar to the corresponding contents in A. tanguticus determined in our study, with the exception of $\mathrm{K}, \mathrm{Li}$, and $\mathrm{V}$, the $\mathrm{K}$ content was higher, and the $\mathrm{Li}$ and $\mathrm{V}$ contents were lower than in the current study [28]. Many factors may contribute to the diversity in the elemental contents among $A$. tanguticus plants with different geographical origins, including plant species characteristics, and soil characteristics (e.g., soil cation exchange capacity, pH) [29].

In this study, we developed a method for determining the geographical origin of $A$. tanguticus on the basis of a PCA and OPLS-DA. This method can efficiently distinguish $A$. tanguticus samples from different locations. The PCA and OPLS-DA results revealed a relationship between the A. tanguticus growing regions and the contents of various elements. The selected regions in China were geographically separated, with different climatic, and soil conditions as well as distinct elemental characteristics.

Accordingly, our multivariate analysis can rapidly, accurately, and efficiently trace the geographical origins of $A$. tanguticus.

The observed difference in the ability of plants to take up various elements from the soil may reflect the differential importance of the elements for $A$. tanguticus growth, development, and metabolism. The uptake of elements from the soil by the roots is influenced by several factors, including cation exchange, cellular transport, rhizosphere effects and soil characteristics which can be affected by root respiration and reactions involving root secretions [30,31]. Additionally, $\mathrm{Be}, \mathrm{Ca}, \mathrm{Li}$, and $\mathrm{P}$ can be transported from $A$. tanguticus roots to aerial part relatively easily. The TF values of $\mathrm{Be}, \mathrm{Ca}, \mathrm{Li}$, and $\mathrm{P}$ were greater than 1.0, implying these elements are needed by aerial plant parts. At the same time, the transport of elements in plant tissues and organs involved processes: movement into phloem and xylem, accumulation, storage. Intraspecific differences in the elemental contents of the roots and aerial parts may be associated with the natural ability of plants to select elements from the soil and transport them to the aerial tissues and organs [32].

\section{Conclusions}

To the best of our knowledge, this is the first report describing the element fingerprinting and geographical classification and authentication of A. tanguticus via a PCA and OPLS-DA as well as the relationship between plant and soil elemental contents. We developed a method involving ICP-OES coupled with microwave-assisted digestion for an analysis of multiple -elements in $A$. tanguticus. The results indicated that $A$. tanguticus from different areas had distinct element fingerprint that could be 
used to discriminate samples from different geographical origins. Furthermore, multi-element signatures were used to divide samples with different geographical origins into three groups. The $\mathrm{Ni}, \mathrm{Cu}, \mathrm{Mo}, \mathrm{Mn}, \mathrm{Be}$, Co V, Zn, Al, and Fe contents in the RAT samples, the K, Mo, Be, Al Fe Mg, Na Ba Li, and Sr contents in the soil samples, and the $\mathrm{Li}, \mathrm{Be}$, and $\mathrm{Cu}$ content in the AAT samples were the most important discriminant variables in the OPLS-DA model. The method developed in this study may be useful for identifying various herbs and determining their geographical origins. Furthermore, the multi-element content in $A$. tanguticus depends on the soil conditions in a particular geographical region. Intraspecific differences in AF and TF are associated with the natural ability of plants to select and transport specific elements and may reflect the stress resistance mechanisms that have enabled plants to adapt to different environmental conditions.

\section{Methods}

\section{Sample collection}

The aerial parts (AAT) and roots (RAT) of A. tanguticus were collected in August 2020, in Qinghai (QH), Gansu (GS), Sichuan (SC), and Tibet (XZ) in China. Samples were collected at altitudes ranging from $2700 \mathrm{~m}$ to $4100 \mathrm{~m}$ above sea level (latitude: $30^{\circ}-38^{\circ}$; longitude: $95^{\circ}-102^{\circ}$ ) (Fig. 5). Three $A$. tanguticus samples and three soil samples were collected at each location. Ultrapure water was obtained from a MilliQ system (Millipore, USA), ultrapure $\mathrm{HNO}_{3}$ and hydrogen peroxide were purchased from Jingrui (Suzhou, China).

\section{Sample preparation}

Briefly, $0.2 \mathrm{~g}$ plant sample was mixed with $10 \mathrm{~mL} \mathrm{HNO}$ and $2 \mathrm{~mL}$ hydrogen peroxide in a poly tetra fluoro ethylene digestion vessel and then incubated for $12 \mathrm{~h}$. Additionally, $0.2 \mathrm{~g}$ soil sample was mixed with 10 $\mathrm{mL} \mathrm{HNO} 3,5 \mathrm{~mL}$ hydrofluoric acid and $5 \mathrm{~mL}$ perchloric acid in a poly tetra fluoro ethylene digestion vessel and then incubated for $12 \mathrm{~h}$. The samples were digested using a microwave assisted digestion system as described by Chen et al [33]. The digestion solution was diluted to $50 \mathrm{~mL}$ using ultrapure water and then stored in a tube until analyzed.

The standard solution comprising $\mathrm{Al}, \mathrm{Ba}, \mathrm{Be}, \mathrm{Ca}, \mathrm{Co}, \mathrm{Cu}, \mathrm{Fe}, \mathrm{K}, \mathrm{Li}, \mathrm{Mg}, \mathrm{Mn}, \mathrm{Mo}, \mathrm{Na}, \mathrm{Ni}, \mathrm{P}, \mathrm{Sr}, \mathrm{V}$, and $\mathrm{Zn}$ (National Research Center for Reference Materials, Beijing, China) was diluted to $0-200 \mu \mathrm{g} / \mathrm{L}$ using $5 \%$ $\mathrm{HNO}_{3}$. The GBW10052 green tea standard was used to verify the precision and accuracy of the analysis.

\section{Analytical procedure}

The elemental contents of AAT, RAT and soil were determined using the Optima 8000 ICP-OES system (PerkinElmer, Shelton, USA), with the following main conditions: RF power, 1300 ; auxiliary gas, $0.2 \mathrm{~L} / \mathrm{min}$; nebulizer gas, 1.2L/min; and sample uptake, $1.0 \mathrm{~L} / \mathrm{min}$.

\section{Statistical analysis}


Graphs were created using SigmaPlot 12.5 (Systat Software, Inc., Point Richmond, CA, USA). Pearson's correlation analysis, and the principal component analysis (PCA) were performed using the SPSS 18.0 software package (SPSS Inc., USA). The orthogonal partial least-squares discriminant analysis (OPLSDA) was performed using SIMCA (Umetrics, Sweden). The elemental accumulation coefficient (AF) was calculated using the following formula:

$\mathrm{AF}=\mathrm{C}_{\text {root }} / \mathrm{C}_{\text {soil, }}$ where $\mathrm{C}=$ concentration of the element $(\mathrm{mg} / \mathrm{kg})$

The elemental transfer coefficient (TF) was calculated using the following formula:

$\mathrm{TF}=\mathrm{C}_{\text {aerial }} / \mathrm{C}_{\text {root}}$, where $\mathrm{C}=$ concentration of the element $(\mathrm{mg} / \mathrm{kg})$

\section{Declarations}

\section{Ethics approval and consent to participate}

Not applicable

\section{Consent for publication}

Not applicable

\section{Conflict of interest}

All authors declare that they have no conflict of interest.

\section{Availability of data and material}

The datasets used and/or analysed during the current study are available from the corresponding author on request.

\section{Fundings}

This work was supported by National Key Research and Development Program of China (2019YFC0507404), Qinghai Science and Technology Achievement Transformation Project (2021-SF149), Joint Grant from Chinese Academy of Sciences-People's Government of Qinghai Province on Sanjiangyuan National Park (LHZX-2020-09), and Key deployment project of Chinese Academy of Sciences (ZDRW-ZS-2020-2).

\section{Authors' contributions}

GZ designed the experiments; $\mathrm{CC}, \mathrm{JL}$ and BW established and validated the methods. CC and $\mathrm{YX}$ were involved in writing of the manuscript. All authors read and approved the final manuscript.

\section{Acknowledgements}


We thank Xiaoyan Jia (Chinese Academy of Sciences Key Laboratory of Tibetan Medicine Research, Northwest Institute of Plateau Biology, Xining, China), and Shoulan Bao (Chinese Academy of Sciences Key Laboratory of Tibetan Medicine Research, Northwest Institute of Plateau Biology, Xining, China) for sampling assistance.

\section{References}

1. Wang H, Zhang XF, Chen GC, Li TC, Zhou GY, Shen JW. Comparative study of contents of four TAs in cultural and wild Anisodus tanguticus. Acta Bot Boreal. 2005; 25:575-577.

2. Zhang XF, Wang H. The variation of the contents of four TAs in Anisodus tanguticus. Acta Bot Boreal. 2002; 22: 630-634.

3. Boros B, Farkas A, Jakabova S, Bacskay I, Kilar F, Felinger A. LC-MS quantitative determination of atropine and scopolamine in the floral nectar of Datura Species. Chromatography. 2010; 71:43-49.

4. Drager B. Biotechnology of Solanaceae alkaloids: A model or an industrial perspective. In Medicinal Plant Biotechnology, Kayser O, Quax WJ (eds). WILEY-VCH Verlag: Weinheim. 2007; 237-265.

5. Oniszczuk A, Waksmundzka-Hajnos M, Gadzikowska M, Podgórski R, Oniszczuk T. Influence of sample preparation methods on the quantitation of selected TAs from herb of Datura innoxia Mill. by HPTLC. Acta Chromatogr. 2013; 25: 545-554.

6. Miao LL, Zhou QM, Peng C, Meng CW, Wang XY, Xiong L. Discrimination of the geographical origin of the lateral roots of Aconitum Carmichaelii using the fingerprint, multicomponent quantification, and chemometric methods. Molecules, 2019; 24:4124-4137.

7. Long WJ, Wu HL, Ming TW, Lu YD, Zhu CR, Qin Y. Fast identification of the geographical origin of Gastrodia elata using excitation-emission matrix fluorescence and chemometric methods. Spectrochim Acta Part A: Mol and Bio Spect. 2021; 258:119798-119805

8. Jiménez-Carveloa AM, Lozanob VA, Olivieri AC. Comparative chemometric analysis of fluorescence and near infrared spectroscopies for authenticity confirmation and geographical origin of Argentinean extra virgin oliv oils. Food Control. 2019; 96:22-28.

9. Liu HL, Zeng YT, Zhao X. Improved geographical origin discrimination for tea using ICP-MS and ICPOES techniques in combination with chemometric approach. J Sci Food Agric. 2020; 100:35073516.

10. Pierluigi M, Alessandro P, Marianna B, Emilio C. Assessment of geographical origin and production period of royal jelly by NMR metabolomics. Chem and Biol Technol Agric. 2020; 7: 24-37.

11. Ma XF, Fan LL, Mao FY, Zhao YS, Yan YG, Tian HL, Xu R, Peng YQ, Sui H. Discrimination of three Ephedra species and their geographical origins based on multi-element fingerprinting by inductively coupled plasma mass spectrometry. Sci Rep, 2018; 8:10271-10280.

12. Zhao YS, Ma XF, Fan LL, Mao FY, Tian HL, Xu R, Cao Z, Zhang XH, Fu XY, Sui H. Discrimination of geographical origin of cultivated Polygala tenuifolia based on multi-element fingerprinting by inductively coupled plasma mass spectrometry. Sci Rep, 2017; 7:12577-12584. 
13. Maggi L, Carmona M, Kelly SD, Marigheto N, Alonso GL. Geographical origin differentiation of saffron spice (Crocus sativus $\mathrm{L}$. stigmas)-Preliminary investigation using chemical and multielement $(H, C, N)$ stable isotope analysis. Food Chem, 2011; 128:543-548.

14. Squadrone S, Brizio P, Stella C, Mantia M, Pederiva S, Giordanengo G, Pistone G, Maria CA. Distribution and bioaccumulation of trace elements and lanthanides in apples from Northwestern Italy. J Trace Elem Med Biol. 2020; 62:646-653.

15. Shen SG, Xia LY, Xiong N, Liu ZH, Sun HW. Determination of the geographic origin of rice by element fingerprints and correlation analyses with the soil of origin. Anal Methods. 2013; 5:6177-6185.

16. Pepia S, Sansoneb L, Chiccac M, Vaccaro C. Relationship among geochemical elements in soil and grapes as terroir fingerprintings in Vitis vinifera L. cv. "Glera". Geochemistry. 2017; 77:121-130.

17. Moe SM. Disorders involving calcium, phosphorus, and magnesium. Prim Care. 2008; 35:215-237.

18. Stone MS, Martyn L, Weaver CM. Potassium intake, bioavailability, hypertension, and glucose control. Nutrients. 2016; 8:444-457.

19. Gröber U, Schmidt J, Kisters K. Magnesium in prevention and therapy. Nutrients. 2015; 23:81998226.

20. Maret $W$. The Metals in the biological periodic system of the elements: concepts and conjectures. Int J Mol Sci. 2016;17,66-73.

21. Roohani N, Hurrell R, Kelishadi R, Schulin R. Zinc and its importance for human health: an integrative review. J Res Med Sci. 2013; 18:144-157.

22. Gruzewska K, Michno A, Pawelczyk T, Bielarczyk H. Essentiality and toxicity of vanadium supplements in health and pathology. J Physiol Pharmacol. 2014; 65, 603-611.

23. Wu X, Li Y, Wang Q, Li W, Feng Y. Effects of berberine and pomegranate seed oil on plasma phospholipid metabolites associated with risks of type 2 diabetes mellitus by U-HPLC Q-TOF-MS. J Chomatogr B. 2015; 1007, 110-120.

24. Senbayram M, Gransee A, Wahle V, Thiel H. Role of magnesium fertilisers in agriculture: plant-soil continuum. Crop Pasture Sci, 2016; 66, 1219-1229.

25. Xu JY, Zhou GY, Chen GC. Determine elements of $A$. tanguticus by atomic absorption spectroscopy. Chin J of Anal Labor, 2009;12, 258-259.

26. Li TC, Chen GC, Gan QL, Zhou GY. Character of mineral element for cultivator A. tanguticus of Xining in Qinghai province. J of Anhui Agri Sci. 2006; 34, 4648-4649.

27. Zhao XS, Lin PC, Liang YX. Cluster analysis for trace elements of Tibet medicine Hypecoum leptocarpum from different regions of Qinghai. J of Anhui Norm Univer (Natural Science), 2021; 44, 349-353.

28. Chen YX, Yu MG, Xu J, Chen XC, Shi JY. Diferentiation of eight tea (Camellia sinensis) cultivars in China by elemental fingerprint of their leaves. J Sci Food Agric, 2009; 89, 2350-2355.

29. Qi Y, Pi Z, Liu S, Song F, Lin N, Liu Z. A metabonomic study of adjuvantinduced arthritis in rats using ultra-performance liquid chromatography coupled with quadrupole time-of-flight mass spectrometry. 
Mol BioSys. 2014; 10, 2617-2625.

30. Kabata-Pendias A, Pendias H, Trace Elements in Soils and Plants. CRC Press, Boca Raton, 2001.

31. Chopin EIB, Marin B, Mkoungafoko R, Rigaux A, Hopgood MJ, Delannoy E, Cancès B, Laurain M. Factors affecting distribution and mobility of trace elements $(\mathrm{Cu}, \mathrm{Pb}, \mathrm{Zn})$ in a perennial grapevine (Vitis vinifera L.) in the Champagne region of France. Environ Pollut, 2008;156, 1092-1098.

32. Ko BG, Vogeler I, Bolan NS, Clothier B, Green S. Kennedy J. Mobility of copper, chromium and arsenic from treated timber into grapevines. Sci Total Environ. 2007; 388, 35-42

33. Chen C, Shao Y, Li YL, Chen T. Trace Elements in Lycium barbarum L. Leaves by inductively coupled plasma mass spectrometry after microwave assisted digestion and multivariate analysis. Spectrosc Lett. 2014; 48:775-780.

\section{Figures}

- Sampling sites

Vegetation type

Forest

Scrub

Meadow

Steppe

Desert

Wetland

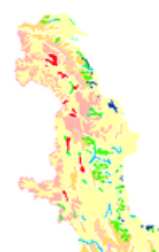

Sub-alpine vegetation

Others

\section{Figure 1}

The fingerprint of each multi-element distribution of $A$. tanguticus. 
$\rightarrow$ Al $\rightarrow$ MeAt

$-1$

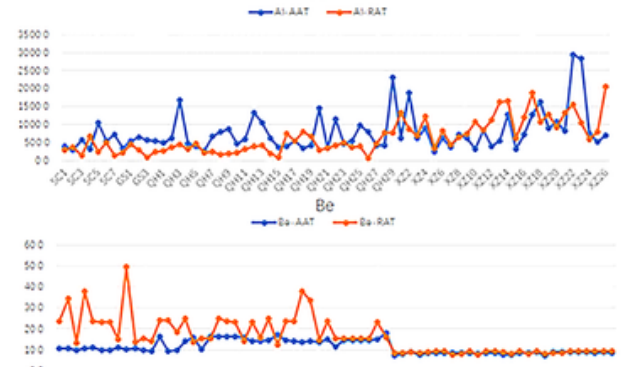

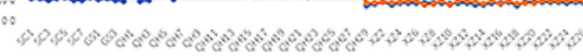

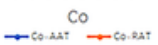

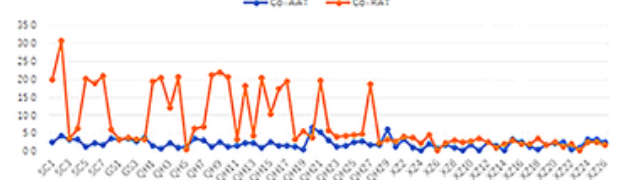

- ${ }^{\mathrm{Fent}} \mathrm{Fe}$ -

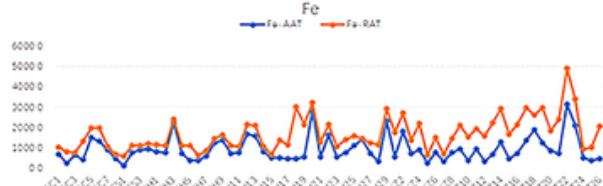

$-\mathrm{x}^{\mathrm{K}}-\mathrm{x}$

: $\rightarrow$ Mn $\rightarrow$ m.

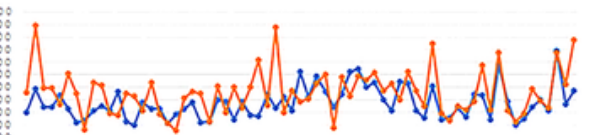

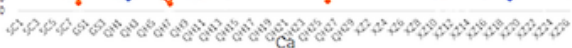
$: 50000$

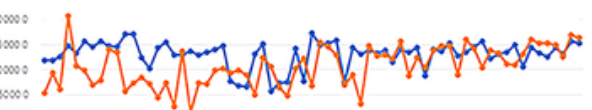

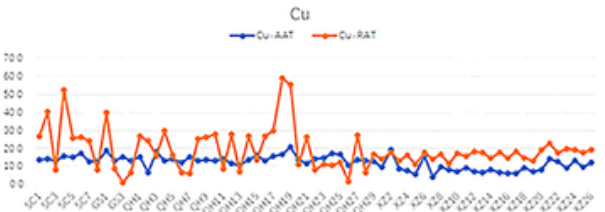

$\rightarrow$ Lis

:

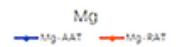

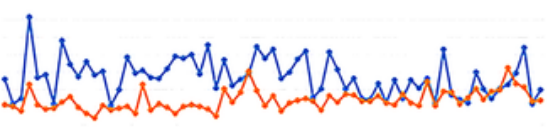

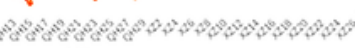
-N ont - Mo

:

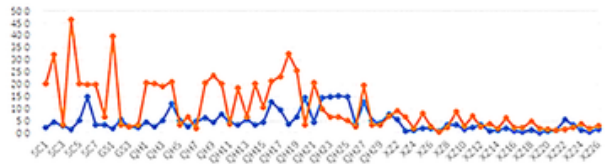

$\rightarrow \quad N a+\infty$

$\rightarrow N^{N i} \rightarrow$.

: N

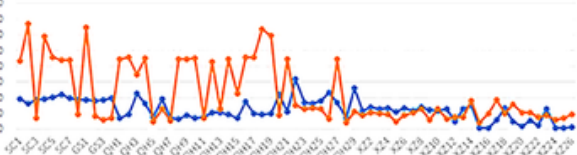
$\rightarrow{ }^{p} \rightarrow$. Ant

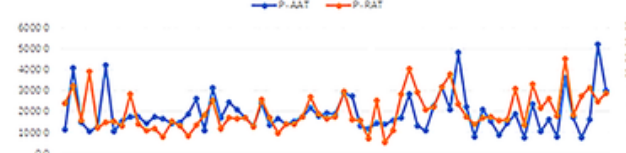

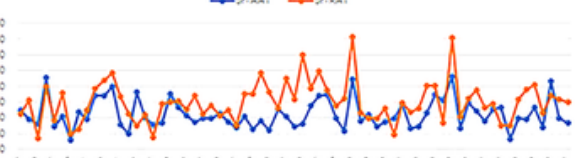

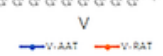

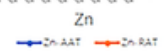

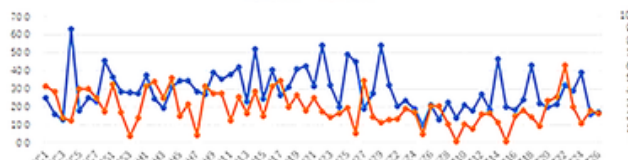

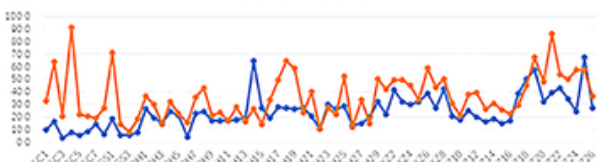

Figure 2

a) Score plot with the first two principal components of $A$. tanguticus. b) loading plot of PC1 and PC2 of A. tanguticus.

Page 13/15 

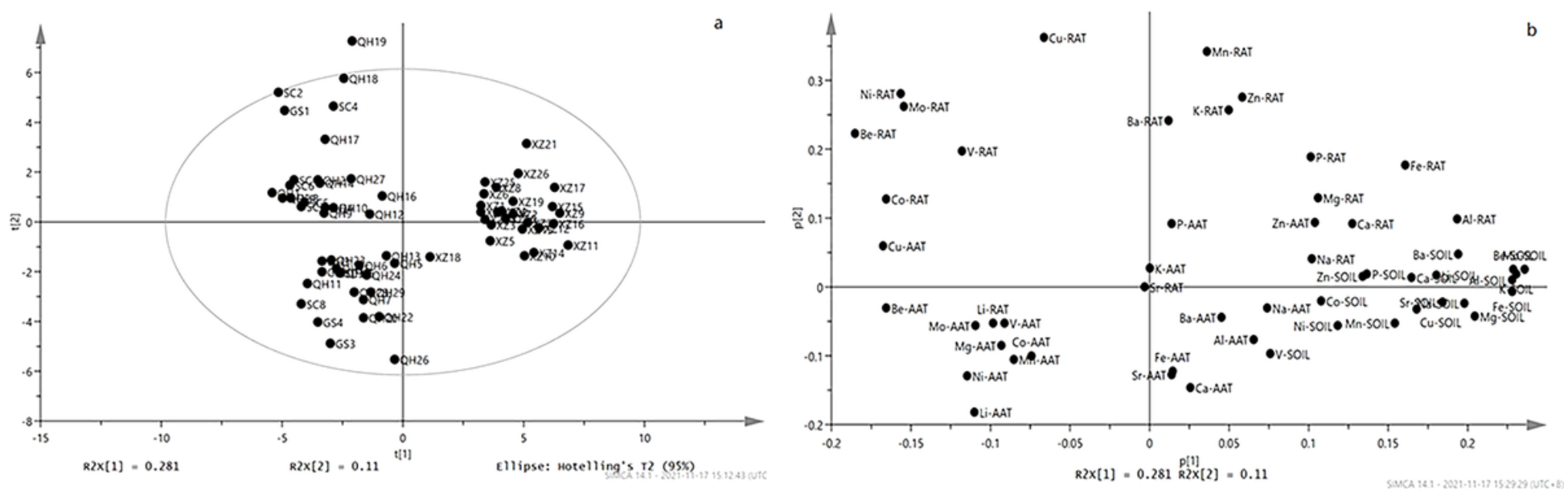

Figure 3

Comparison of OPLS-DA results from multi-elements of A. tanguticus. Score plot (a), loading plot from OPLS-DA (b), and VIP plots of variables (c).
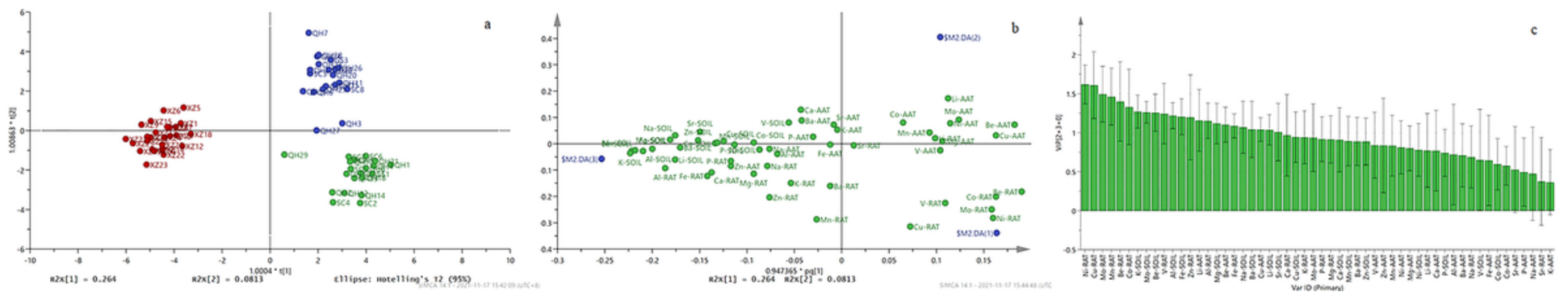

Figure 4

Correlation of multi-elements of different parts of $A$. tanguticus and soil.

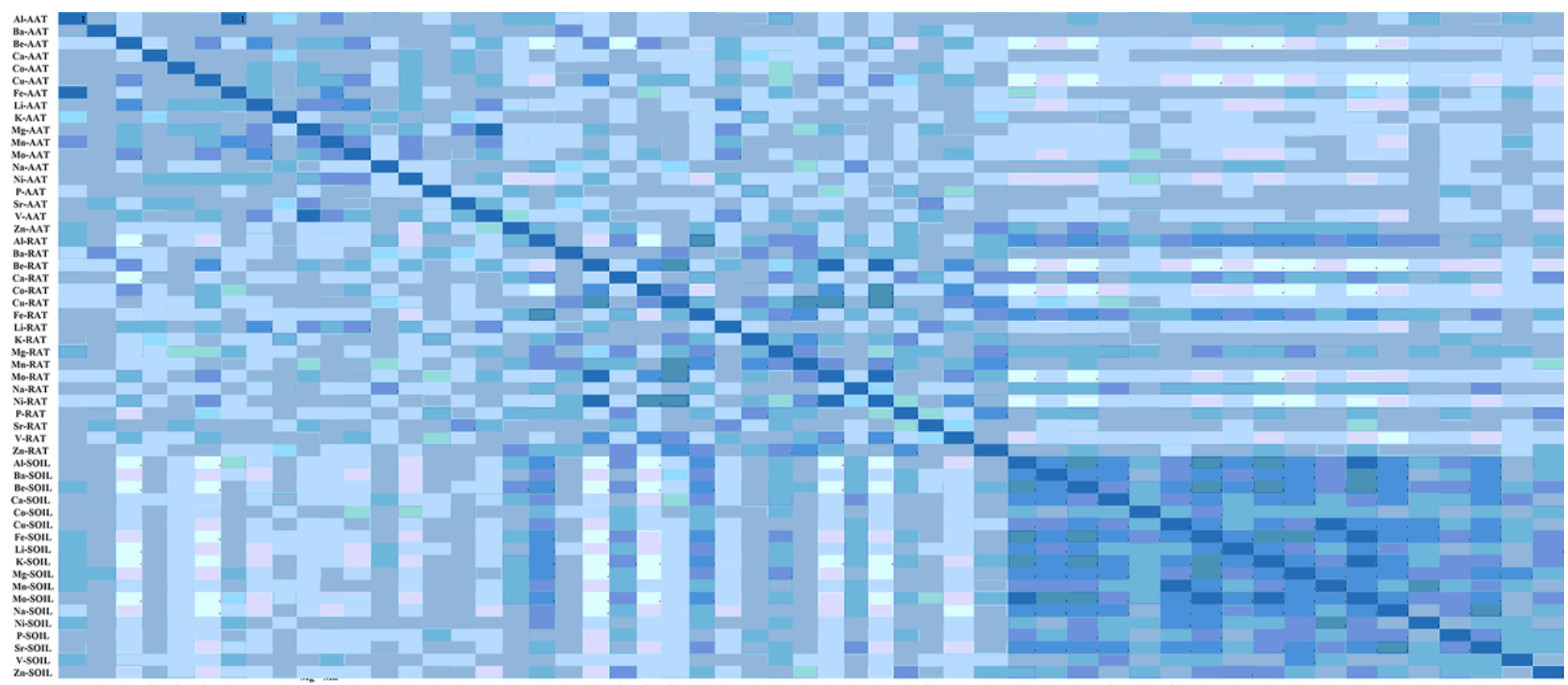

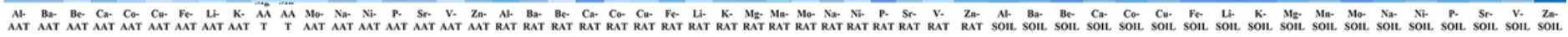


Figure 5

Geographical distribution of the regions of $A$. tanguticus were collected.

\section{Supplementary Files}

This is a list of supplementary files associated with this preprint. Click to download.

- supplementarymaterial.xlsx 